Journal of Development and Communication Studies, Vol. 7. Nos. 1 \& 2, January- December, 2020 ISSN (Online \& Print): 2305-7432.

http://www.devcomsjournalmw.org

\title{
Media Power and Nigeria's Consolidating Democracy
}

Victor Jatula, Department of Communication, University of Utah (Asia Campus), South Korea. Email: vjatula@gmail.com

\begin{abstract}
In emerging democracies with weak public institutions, low literacy level, deep-seated ethnic rivalry, and history of centralized, authoritarian rule; to what extent does media agenda-setting influence the political process? The press/politics nexus in consolidating democracies is critical to understanding intricate yet overlapping connexion between politics and development in the Third World. This study examined if media-power shape elections and regime outcomes in Nigeria? Using semi-structured interviews (and incorporating News-Game research tool), findings indicate that Nigeria's two-decade-old democracy remains volatile, fragile, and vulnerable. This vulnerability is complicated by long-standing religious, ethno-regional political suspicions; and overburdened with shifting media ecology, particularly social media disinformation and propaganda. These complexities allow a politics of privilege, class, and power that not only ensures its preservation but also insulates the political elite from public outcry and media pressure. In conclusion, evidence indicates that media power exerts limited influence on elections and regime outcomes. The study recommends renewed effort to investigate power.
\end{abstract}

Keywords: Nigerian politics, agenda-setting, mass media, democracy, underdevelopment. https://doi.org/10.4314/jdcs.v7i1-2.9

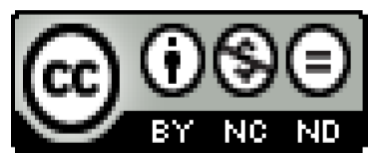

(C) 2020. The author. This work is licensed under the Creative Commons Attribution 4.0 International License (CC-BY-NC-ND). Users may freely share and redistribute this work provided that the author and the Journal of Development and Communication Studies are fully acknowledged. Users may not tweak or remix and offer this work for sale. The full license may be accessed at https://creativecommons.org/licenses/by-nc-nd/4.0/

\section{Introduction}

In Western democracies, free flow of news and information made available by an unrestricted and independent press is a fundamental pillar of inclusive governance and 
a means to specific ends- social equality, political representation and development. This is underpinned by the assumption that democracy depends on media influence- one that promotes boundless political, social and economic debates and reports the actions of political leaders to the electorate. "Press freedom is not only an indispensable pillar of democracy, but also important for the long-term sustainability of social and economic development (Senghore, 2012, 1). The liberal press therefore exerts power and political influence through their ability to reach broad audiences with news and information that shapes public life. An independent press performs informative roles, ensures plurality in the public sphere and more importantly, weave together different threads of a multicultural, multiparty society and connect members of that community ideologically and politically; thereby fostering popular culture that shapes the public's worldview (Robertson, 2018).

In emerging democracies, to what extent does media influence politics and democracy? This paper, an evaluation of media effect on an evolving, consolidating democracy sought to analyse the impact, if any, of media power in Nigeria- a nonWestern, post-colonial, unindustrialized nascent democracy in sub-Sahara Africa with a history of authoritarian rule (colonial and military), complex ethnoreligious polarisation and weak public institutions. Has media power shaped election results and regime outcomes since a new political dispensation took-off in 1999? That year, Nigeria transformed from authoritarian rule into a democracy. Now two decades old, politics is characterised by multiparty, regular and periodic voting. With seven presidential elections and steady transfer of political power, democracy is consolidating. Civil society, opposition groups and the media operate with constitutionally-guaranteed freedoms. News organisations are more economically viable, more independent and more assertive. In 2011, Oso (2011) observed that no news business of influence in Nigeria is owned or tied directly to the apron strings of a political party. This independence, coupled with its agenda-setting force, Oso added, have allowed the media break free from partisan political reporting and hold political office holders accountable as they did during decades of post-independent authoritarian regimes and a century of British imperial influence.

However, the effect of media power on national politics since democratisation in 1999 is a subject of much controversy. On one hand, Adesoji (2010) asserts that politics in Nigeria is largely shaped by media power through public opinion, press agitation and media agenda. Consequently, the press, perceived as powerful is often owned, recruited and/or engaged by politicians and political parties to influence public attitude and win elections. According to Kukah (2012), continued proliferation of new titles (print and online) particularly in Lagos and Abuja since 1999 is proof that media agenda-setting still plays a key role in contemporary Nigerian politics. Kukah argued further that media ownership by politicians and regional coalitions is an enduring feature- one that dates back to 1922. Adesoji, Kukah and others reckon that Nigeria's news media is 
independent, detached from partisan politics and well-positioned to sway voting patterns and shape regime outcomes.

On the other hand, media influence on Nigerian politics is increasingly questioned amidst worsening political corruption, state inefficiency and radical insurgency. News production is moulded by political and commercial pressure which complicates and often compromises the media's ability to fulfil its constitutional role (Jatula, 2017). According to the British Broadcasting Corporation: "The (Nigerian) media has long been accused of being beholden to special interest groups, often placing financial interests above public interest in setting editorial priorities. Politicians and commercial advertisers hold great sway in decisions on story selection and publication..." (BBC Report, 2019). Public distrust of the media, accentuated by fake news, social media propaganda and deliberate disinformation have also eroded trustworthiness to the extent that the public no longer trust the press. A study by Madrid-Morales \& Wasserman (2019) found that 93 per cent Nigerians believe they are regularly exposed to fake news and are likely to trust the media less. The authors indicated that social media in Africa's largest democracy is not empowering people to make sound political decisions; rather, it is decreasing public ability to make good judgements.

This paper- an evaluation of media power and its effect on Nigeria's consolidating democracy seeks to reconcile opposing yet divergent views about media influence on politics using the lenses of media effects. Does democracy in Africa depend on press freedom? Is media influence powerful, limited or negotiated? An investigation of press and politics nexus is fascinating yet complex; particularly in a system in which politics has not always depended on persuasion, openness, media freedom and public participation but on military fiat and centralised control. It is hoped that an analysis of ongoing struggle for power in oil-rich Nigeria- its concentration and use by a privileged few on one hand and on the other hand, media pressure to redistribute power, democratise decision making and restructure resource control especially in a large, multiethnic and dynamic Nigeria will provide insightful understanding of media transformations and political reorganisation in post-colonial Africa.

\section{Theoretical framework: Media Agenda-Setting}

The normative theory of the press asserts that the media performs symbiotic roles of mediating between the state and the governed. The press it is argued contribute to democracy and good governance by surveying the political landscape, acting as watchdogs of political actors, providing forums for political debate, articulating public opinion and setting policy agenda (Keane, 1991). This cardinal idea is premised on the media's supposed ability to influence public opinion and by extension democracy. It is believed that the press is able to raise the importance of an issue in the public space and among policy makers. The media may not directly tell the public what to think, rather, they identify issues people should think about and through salience, repetition, emphasis 
and analysis; the public is made aware of the importance attached to issues of public relevance (Graber, 2003). Although the public is able to determine issues it deems relevant, media analysis raises the salience of issues in the public domain.

The link between media agenda, public agenda and politics was sketched in the Chapel Hill study by McCombs and Shaw (1968). Voters in the United States presidential election were asked to name the most important issue of the day and their responses closely reflected the patterns of news coverage during the preceding six months of media coverage exposed to them. The agenda of a news organization is discerned in its pattern of coverage of public issues over a period of time. Public attention is drawn to issues emphasized in the media. The correlation between media agenda and the public discourse is such that the former influences the latter (McCombs 1991). Through agendasetting, news organizations shape public understanding and perspectives on issues.

Media agenda-setting is a two-tracked lane and can be problematic for democracy. The selection and omission process involved in determining news content and setting media agenda can unduly influence the electoral process. In 1988, Chomsky argued that through propaganda, mainstream news in the United States is used to manufacture consent, sway public opinion, affect election results and influence political decisions. Outside the United States, Herman \& McChesney (2009) have described the dominant news media as largely composed of international conglomerates from Europe and North America that use concentrated advertising-based commercial interest to perpetuate Western media imperialism through technology, massification and free trade agreements. This allows them dominate control of information flow between the industrialized North and the underdeveloped South. These dominant corporations according to Ostgaard (1965) along with their narratives treat the culture of the industrial nations as superior and place them at the top of their hierarchy. In Western media narratives, Africa is routinely portrayed in negative terms; “... perennially problematic, unworthy, deplorable... without saying much about Africa's strategic importance to industrial economies" (Ostgaard, 1965: 12). Africa in mainstream Western media narrative is depicted by extremes of hunger, famine, poverty, disease, war and political instability (Okigbo, 2001). These concerns highlighted in critical scholarship were central to the MacBride Report (1980), commissioned by UNESCO for the study of communications problems.

The MacBride Report recommended a new world information and communication order that advocated for democratisation of global information flow and strengthening of national media to reduce dependence of external, neo-liberal forces. Although the United States and United Kingdom disagreed with UNESCO's report and subsequently withdrew their membership; the power of the media in changing politics and society, globally and locally was never in question. More specific to media and democratisation in Africa, a free and independent press was conceptualised as an essential instrument of development and deemed critical to the survival and success of 
democracy across the continent (Windhoek Declaration, 1991). As observed by Randal (1993), the long history of media agitation in Africa and their close association with movements for national independence, particularly during colonialism demonstrated the political power of the press as a great mobilising force. The newly emergent political class in post-independent Africa, in a bid to consolidate their hold on power grew intolerant of press criticism to the extent that legal, economic and violent, police force was employed to supress and control the media. Despite direct political constraints, the press survived as the voice of the voiceless, a force opposed to authoritarian rule and a window through which the world saw, first hand, the sheer brutality and undemocratic state of politics in Africa. Foreign media organisations- BBC, VOA and others also provided incentives for democratisation both politically and otherwise. In less direct forms, they revealed through entertainment a life of freedom available in the West, a view of the outside world. As a consequence, they created expectations in Africa, of a good life, making hardship less acceptable. Politically, they provided a model for investigative news reporting, generated alternative news content that negated controlled information from within; and sowed ideological seeds that fuelled agitation for liberation movements in many parts of the continent. In sum, the press, both local and global, contributed significantly to the democratic process in Africa.

\section{Agenda-Setting in Nigerian Politics}

Media agenda in Nigeria unfolded in three phases- pre-colonial, colonial and postcolonial eras. In the first phase, missionary newspapers such as Iwe Irohin fun awon EgbaNigeria's first newspaper became the platform through which locals expressed their displeasure with Britain's imperial influence. Originally established to proselytise natives, Iwe Irohin soon became embroiled in local politics and often incurred the wrath of Crown representatives (Omu, 1976). The paper along with other missionary newsprints were caught in the web of shifting political undercurrents that witnessed increasing Europe-based humanitarian, anti-slavery, evangelical work that spread beyond the coast of West Africa. It was a period of expanding British political influence and power (Ade Ajayi, 1965). As trade in African slaves across the Atlantic gave way to trade in commodities, extensive competition among chartered European companies ensued. Each scrambled to secure trade monopoly and/or lay claim to vast territories across Africa. Inevitably, Britain exerted increasing political and economic control over territories in the Niger area that became recognised at the Berlin Conference of 1888 (Hopkins, 1975; Afigbo, 2006). Pre-colonial missionary newspapers, though limited in quality, circulation and lifespan, opened the door for a press agenda that criticised Britain's takeover of Nigeria.

At the dawn of British rule in 1900, media opposition became more assertive and widespread. Colonial rule necessitated, not only political control but also economic exigencies that included trade monopoly, imposition of taxes, extraction of surplus, and 
administrative mergers. Around 1914, a new generation of newspapers emerged with a more aggressive and confrontational agenda. These papers were owned and edited by educated and aggrieved Nigerians; discontent with colonial politics and Britain's domineering powers (Omu, 1976). Colonial-era newspapers were radical and antiimperial. They called for social reforms and challenged inequality. Papers like- Lagos Daily News owned and edited by Herbert Macaulay, West African Pilot- Nnamdi Azikwe and Nigerian Tribune- Obafemi Awolowo- progressively played critical roles in clamouring for abolition of unfair taxes and minority rule. They galvanised public opinion, influenced constitution making, pressured Royal authorities in London and called for decentralised decision making. Media agenda, especially in the 1950's shifted towards decolonisation, self-rule and later independence (Sklar 1963).

After independence in 1960, media agenda transformed into support for national progress, economic development and self-sustenance (Ikime, 1980). Good governance was central to these transformations and the media engaged in development journalism, characterised by promoting state initiatives and providing a platform through which government plans, policies and dialogue would fester. However, in the late-60s, an adversarial press would emerge as military rule became entrenched. Constitutional crisis in Western region, partisan politics at the Federal government and tensions between Nigeria's major ethnic groups brought to an abrupt end, Nigeria's First Republic (19601965). Military rule from 1965 curtailed party politics, elections and press freedom. The outbreak of Nigeria/Biafra War (1967-70) ended in more military rule to the extent that Nigeria's Second (1979-1983) and Third Republics (1993) were both hijacked and shortlived. The press changed into outspoken critics of military rule. By the 1990s, the press had become a formidable influence on national politics. They set political agenda, shaped public debate and influenced popular opinion. Newspapers across Nigeria were united against military rule and everything the military stood for- human rights abuses, media suppression, political dictatorship, and superimposed decrees. And in spite of legal, economic, political and physical suppression that included detentions, imprisonments and proscriptions of news publications and media organisations; the press remained undaunted and irrepressible (Siollun, 2013). By 1999, local and international pressure brought military rule to its knees; transforming Africa's most populous nation into a democracy. Twenty years on, what political influence does the press exert?

\section{Methodology}

To investigate media power on Nigerian politics, semi-structured interviews were conducted with media professionals to gather data for the study. Three reasons justified this method: one, needed qualitative data is easy to collate from frontline news professionals. Two, interviews in general are faster and flexible to arrange and conduct, compared to focused group discussions or participant observation. Data generated during interview sessions are larger in quantity than mailed questionnaires. Finally, 
interview facilitators have control over the order of questions, and can judge the spontaneity of respondents. The interviewer can also judge non-verbal actions and/or inactions; and if required, follow up with clarifying questions or comments (Newton, 2014).

In total, 18 semi-structured interviews were conducted in Lagos (South) and Abuja (North). Each participant was personally contacted both by email and a follow-up phone call to ascertain their willingness and readiness to participate in the study. This notwithstanding; some participants declined after initial consent. While presenting the purpose of research, participants were reassured of absolute confidentiality and this stimulated robust commentaries. Participants included: news reporters (9), editors (2), and senior correspondents (7). They were all into political reporting. Some participants were randomly selected through articles they had published while others were randomly selected. The rationale behind assembling a varied cohort of participants was to gather as much perspectives as is possible from a wide range of media professionals from diverse religious, ethnic and social backgrounds; cut across different news organisations in Lagos and Abuja. The newspapers included Daily Trust (Abuja), Blueprint (Abuja) Tribune (Ibadan), Punch, Guardian and This Day in Lagos. Each interview lasted more than half an hour. Opened-ended questions were used during each interview. All interviews sessions were recorded and transcribed accordingly. Transcripts were analysed following a systematic process which required familiarity with the content of the transcripts before coding sections of text into meaningful units. These were then developed into broader thematic categories.

The use of News-Game was employed as a research tool to elicit comments from participants. According to Kitzinger (1994), News Game is a useful way to engage focused group discussants and focused interview participants using newspaper cutting and media images to draw out comments. Although partakers did not engage in writing alternative news pieces as recommended by Kitzinger, they were vocal and engaged when newspaper cutting were used during interview. It should however be noted that interviewee quotes are presented in several different ways throughout this paper without reference to personal details or private identity. All participants, for fear of reprisal or backlash agreed to be interviewed only on condition of anonymity. Thus, general descriptions, including job title, location of organisation and in some cases, employer's name are only disclosed.

\section{Findings and discussion}

Nigeria was centre stage of profound political, legal and social changes in the 1990s following decades of military rule. Democracy was restored in 1999 and with it came media liberalisation and constitutional reforms of sizeable proportions. It was hoped that these changes, particularly press freedom will transform the political space into a more open democratic system required for economic progress and human development. Two decades after, hopes of a truly democratic system, void of longstanding cronyism and 
prebendal politics of a few, by a few have faded to the extent that media power is yet to reform the system. Evidence points up three factors- media polarisation, commercialisation and public resignation. Together, they combine to perpetuate the development of underdevelopment in democratic Nigeria.

\section{Media polarisation}

Traditional media- Overwhelmingly, interview participants stressed the dominance of news organisations in Lagos and Ibadan as the main conduit pipe of information in Nigeria. According to an Abuja-based reporter with Blueprint newspaper, "The Nigerian press, in reality is the powerful, privately-owned Lagos/Ibadan press. When they speak, the world listen. They are the window through which news and politics about Nigeria is view globally." Multiple reasons account for this. Early political activities and concentration of newspapers in Lagos was influenced by access to an educated workforce, advertising revenue and economics of scale. This view reads Lagos and the South as 'micro-Nigeria' due in part to economic viability. Money and power, it is suggested, operate from this locus so it would be no more than sensible business practice to set up a national news outfits in Lagos or elsewhere in the south. It is therefore fit to situate post-1999 media developments within the global capitalist economic structure of modern Nigeria and argue that news business, first and foremost are private business concerns who primarily want to make profit and Lagos provides that platform.

Journalists based in Abuja (Northern Nigeria) however believe that media outfits in Lagos and Ibadan, regarded as the Lagos/Ibadan press axis often represent the political views of the Yoruba ethnic group in southwest Nigeria. A DailyTrust newspaper reporter in Abuja noted that "It is difficult, if not impossible to divorce the culture of a geography from the character of its press and politics. Culture, politics and the media are all intertwined in southern Nigeria. The Lagos media is therefore not fully representative of all Nigerians" If this comment is exact, it therefore suggests that news platforms in the South have an inherently southern nature, radical in character and Christian by faith; an ideological standpoint that conflicts with the North's conservative political and religious structure. Another reporter from Abuja added that "News content from Lagos-based organisations is an offshoot of the Yoruba conventional culture of criticism, a pronounced history of political struggle and a traditionally radical political system of opposition to oppressive rulers." He stressed that this critical root was further influenced by Christian Enlightenment ideas. In the above narrative, the Lagos press is therefore routinely dismissed by the Muslim North as Western-Christian-Yoruba conspiracy, committed to a secular and liberal-radical order which opposes the conservative-religious political elite from the North. The radical ideology inherent in the South and its politics sets huge expectations on Lagos-based news platforms who in turn frame their content to satisfy news consumption appetites of their readers. Content in Lagos papers must fit the 
accepted framework of the southern readers which mainly consist of south-western worldview.

The issue of Yoruba philosophy and political influence as a dominant stimulus in southern newspapers are here bolstered by a story about the radical and dominant qualities of the southwest. As indicated by a Lagos-based Punch newspaper editor: "The ideological perspective of the Southern elite has become the main framework for moral reference for news in Nigeria and that this perspective has deep historical roots." A remarkable twist of irony suggests that the traditional political legacy of pre-colonial Yoruba societies provides the 'educated' South with a richer range of resources than the ethnically-conservative North. The comments therefore indicate a conflict of interest between the West-oriented, radical South and a traditionalist Muslim North with interlocking religious and political interest in Nigeria. Importantly, the narrative indicates continued dominance of the southern media in setting national media agenda and by extension, controlling national political discourse. It appears that the southern press claims to have a monopoly of understanding of Nigerian politics and national interest than other constituent parts. This creates ground for misinformation and misunderstanding within the polity. This prevailing narrative seeds resistance through its marginalizing of the northern part of the Nigeria. We shall need in this analysis to consider whether the North is silenced- or, more disturbing, misrepresented in the central narrative.

Is news bias against the North? Interview commentaries indicated that a reasonable degree of bias against the north exists in Lagos papers. A Lagos-based reporter with Guardian noted that, "the North is not sufficiently reported in the news. When it is, a third of the coverage is dominated by negative news of violence, illiteracy, disaster and poverty, especially ethno-religious conflicts related to Boko Haram." Another Lagos reporter with This Day added that "bad news about Hausas' is good news in the Lagos press". If these commentaries are accurate, they indicate that news reportage from the South devoted to North is not only biased but significantly lower in quantity. The North, according to a journalist in Abuja is framed as violent, turbulent and volatile. These comments suggest that the north is subtly reported as incompatible with investment and progressive politics. As observed by a Daily Trust editor, it is difficult to quantify both the direct and less obvious linkages between negative reportage of Northern Nigeria and the perception and concentration of poverty in the region, however, media stereotypes in the description and analysis of the North, mainly within the press in Lagos may have contributed to the dearth of investment in the region. According to an editor with Tribune in Ibadan, though owners of the press in Lagos are not necessarily Yoruba; their operational location and rhetoric is ideologically southwest. Lagos-based news platforms therefore function to advance southern elite interests; as a result, their perspectives correlate with southern political agenda. 
The described imbalance in coverage between the North and South and how the press in Lagos dominates national discourse is symptomatic of a deeper tension. The study found that Nigeria's multi-ethnic suspicion in the Middle-Belt region where both north and south meet; resource control controversies and appointments into federal offices which manifest in allegiance to ethnic groups; inter-ethnic antagonism; and hostility towards other groups are drummed up by a section of the press. In placing regional interest above balanced news coverage, the press in the north and south whip up political sentiments by giving prominence to politicians with sectional interest, particularly those who use ethnicity as a political leverage during elections. It is therefore no coincidence that in spite of dwindling circulation and revenue, new titles continue to proliferate in Lagos and Abuja. A Tribune newspaper political correspondent based in the North noted that "shortages in terms of resources, technology and manpower to adequately gather and report news in and about the North may also contribute to stereotypes and biased reporting in both hubs". He added that media owners influence their news titles to support certain candidates during elections. As a consequence, news reports in general may not always be representative or prejudice-free.

Although no newspaper is tied to the apron string of a political party, most dailies are used by regional political elites through advertisement for power contestation. According to a Guardian newspaper editor in Lagos, "Who owns what determines how and what is reported, what is left out and how what is included is framed and covered. Like they say, the fruit does not fall far from its tree." He said further that, "Take Tribune, Punch and Vanguard for example, they are as regional in their outlook as DailyTrust and Blue Print." An editor with DailyTrust, Abuja said, "...negative comments about the north in southern newspapers blames the north and its leadership for Nigeria's woes; describing Hausa/Fulani leaders as wasteful and corrupt. This is not professionalism." Counterclaims are made by reporters from the south. A ThisDay reporter in Lagos noted that, "newspapers in the North constitute an editorial and agenda-setting alliance too". The assumption above is that newspapers in Nigeria are either for or against a region or political party- evidence does not support this. A closer analysis indicated that on certain issues, newspapers within Lagos diverged and disagreed. For instance, although Lagosbased papers display similar characteristics (though in less significant ways), there is clear distinctions between and among them by reason of owner's priorities and political ideology. It is also naïve to suggest that political allegiance in any region in united and similar. The above conflicting trajectories lends support to the view that newspapers in each region (North or South) are editorially aligned. What is, however, not clear is the degree to which these newspapers editorially align. While there are instances where the agenda of a paper is not consistent with that of its region, reporters indicated that it is difficult to separate these two interlocking interests. 
New Media- Facebook, Twitter, WhatsApp, YouTube and Instagram as well as local blogsites- LindaIkeji, Jumia.com and BellaNaija have opened up information flow, political participation and collective engagement in Nigeria. Online news now plays a more significant role in breaking news. Participants noted that as far back as 2012, two major Twitter movements translated into real political action across Nigeria. \#OccupyNigeria- an online protest against the removal of oil subsidy that quickly gather momentum offline, leading to violent demonstrations across major cities. And \#BringBackOurGirls- another Twitter plea to rescue over 250 kidnapped school girls by Boko Haram- a radical Islamist group operating in Northeast Nigeria. This latter movement gained international attention as far as the United States, United Kingdom and Europe. Participants added that more recently, social media was instrumental prior to, during and after elections in 2015 and 2019. According to a Punch newspaper editor in Lagos, "All major political parties and politicians were well-represented on Facebook and Twitter." With a population of over 190 million, 100 million of which are said to be active internet users; migration of political discourse online has never been more evident. According to a Lagos-based journalist, social media offers users, mostly young, urban dwellers with stable internet network; freedom to participate in political conversations and access information, especially breaking news from multiple blog sites and online communities both mainstream and alternative. A Blueprint reporter in Abuja said, amateur videos of political violence on Facebook and Instagram were acted upon by the police, leading to arrests.

Most participants however asserted that, just as politics have moved online; so has ethnic sentiments and political propaganda. Social media news content is not only suspicious but also dubious. An Abuja editor with Blueprint observed that, “...during the recent 2019 presidential elections, social media served as an echo chamber through which disinformation or misinformation were posted, shared and retweeted." In certain cases, ethnic bias was spread by seemingly credible sources and shared by unsuspecting audiences. For example, "it was reported on Twitter that Peter Obi, former governor of Imo state in the south deported northerners from the Owerri- the state capital while he was incumbent governor. Although untrue, this gained plenty of traction online in the build up to 2019 election where Peter Obi contested as Vice Presidential candidate on the People's Democratic Party ticket." A Lagos editor added that, "Yoruba's were reported to be burning Igbo shops in Lagos. These lie was a calculated attempt to incite ethnic tensions among Nigeria's major regional groups." A Guardian newspaper editor in Lagos noted that the platform may have changed; the conversation remains the same- ethnic rivalry and regional suspicion. She added that "Although the medium is neutral, they are being used for political antagonism, bitter political fights and suspicious information." A correspondence in Tribune newspaper, Ibadan pointed out that the immediacy of sharing information without verification and filter also takes away from social media news credibility. "On one hand, the elimination of gatekeepers is hailed as a major benefit of 
social media news however, on the other hand, some form of gatekeeping, that sets apart traditional news platforms would radically increase news credibility online". Multiple instances of falsehood and lies on social media is a cause of public concern.

In sum, media agenda on social media is useful but incoherent, instant but conflicting and pervasive, yet unfiltered. It is a space beset with multiple voices, multiple agenda and multiple allegiances. As observed by an Abuja editor with DailyTrust, "It is increasingly difficult for the public to trust media-entrepreneurs, most of whom are oneman businesses, operating in small spaces. The point of distrust is that these bloggers and online influencers are very susceptible to external funding particularly from politicians and political parties who readily offer cash or endorsements for favourable media content". While this is true in some cases, broad generalisations are inaccurate. According to a Punch reporter, "...unlike traditional organisations with history and reputation; most bloggers are small-scale businesses with little media ethics or background in journalism. It is therefore the case that these low-stake media owners are rumour mills, publicists and propagandists who churn out favourable information for advertisers and sponsors".

\section{Nigeria's commercial press}

The pursuit of commercial success has had a negative effect on the media in general. In the Nigeria context, commercialisation has created public distrust. As observed by a Punch reporter in Lagos, "most readers often tell me that they don't know what to believe between news on social media or in traditional media because both are rigged!" A reporter with Tribune in Ibadan observed that, "In Nigeria, truth is scarce in the press. In theory, the press is free but in practice, advertising money drives news content to the extent that views of advertisers and well-resourced individuals are generously express in the media." This model of journalism is not exclusive to Nigeria. The neo-liberal philosophy is well established in Europe and America but does not necessarily inhibit most news organisations. Its uniqueness in Nigeria is that in trying to raise revenue, many news organisations now devote more pages to advertisement, rather than critical reporting. This has led a systematic repression of investigative news reporting and news with minimum economic value- according to a Daily Trust reporter. The picture that have emerged in the last two decades indicate that commercialisation is the driving force behind news coverage. This is most prominent during elections when media houses practically sell out to the highest bidder without recourse to ideological leanings. According to a Lagos-based reporter with Guardian newspaper, "I know of a Lagos-based paper that you literately can get anything published as news so long as you can pay for it." An Abuja reporter added, "my former boss was very close to Abuja (national government). It is an open secret in the office that we are staunch defender of the government because whoever pays the piper dictates the tune!" 
Two decades ago, Oso (2002) raised concerns over the influence of news commercialisation, arguing that neither ethnicity nor geography is as influential as revenue. Using Oso's newspaper cutting as new-game, a significant number of participants agreed that as more and more media organisations "sell" news, only certain views will dominate the press. And when deliberately-sponsored information is presented as news to broad and unsuspecting audiences, fake news results in misinformation and propaganda, capable to twisting political perception. This, according to an Abuja editor with Blueprint "is not unconnected to what owners want (revenue) as the practice of "cash for coverage" trickles down to every aspect of the news business. According to the editor, "there is a fine balance between objectivity and subjectivity in news reporting. If the scale tilts towards the latter, a media organisation will lose its credibility. If it tilts towards the former, many fear that the organisation may go under like Next newspaper." Most, if not all newspaper of note in Lagos and Abuja are in private hands. In these companies, advertising revenue from politically-motivated content takes precedence over balance, fairness and professionalism in the media.

\section{Media effect on elections and regime outcomes}

In addition to ethnic bias, online propaganda and commercialisation; two other factors limit their influence of the media on politics. First, a significantly low percentage of Nigerians have limited access to news from multiple sources. As noted by a Tribune editor in Ibadan, "Nigeria's voting public is influenced, not by press reports but by religious leaders and local politicians". According to an Abuja editor, "in a country where close to half its total population are illiterate, rural dwellers; media power is mainly limited to literate, urban residents." He added that "there are still some communities in modern day Nigeria that have little or limited access to daily newspapers, constant electricity and stable internet connection, if any. How will these people make informed political decisions without news?" An editor with ThisDay in Lagos, citing a 2017 UNDP report in which over 35 percent of Nigerians are said to be illiterate; said "illiteracy is one of the most fundamental reason for underdevelopment in Africa in general and Nigeria especially. She noted, "it is shameful that in the 21st century, Nigeria has over a third of its people, about 60 million citizens unable to read and write! How effective is media agenda in a nation with 60 million illiterate citizens? It is even more annoying to know that the authorities at different levels of government are not doing enough to address the situation". There is a regional dynamic to this. In comparing the north and south, an Abuja reporter with DailyTrust observed that news penetration is deeper and faster in the south than in the north due to higher levels of education in the former. "In the north, people vote based on religion and ethnic considerations. A typical Hausa/Fulani will not vote for a non-Muslim. And generally in the north, southern politicians are treated with suspicion. Similar sentiments exist in the south but to lesser extents." An analysis of 
voting patterns during national elections since 1960, evidence supports the above claim. An Abuja-based editor asserted that an average voter in the North will always vote his own. He said: "Similar to previous national elections, in 2015 and 2019 elections, northerners overwhelmingly voted for Mohammed Buhari, a Muslim from the north."

Second, Nigeria's elite culture, a legacy of colonial and military rule perpetuates a system that insulates political leaders from media criticism and public outcry. It has been suggested by Campbell (2019) that these elite class have perfect a scheme through which radical media organisations and vocal journalists are censored, discredited or controlled. Bottom-up political change is rare and is often resisted with judicial instruments and state security forces who crush free speech, right to assembly and freedom to demonstrate. Recent high profile examples include the six-month incarceration of Sahara Reporters founder, Omoleye Sowore by state security services "charged with treason, money laundering and "cyberstalking" for allegedly sharing false and insulting information about President Buhari." (BBC, 2019). In 2015, Nnamdi Kanu, leader of the Indigenous People of Biafra (IPOB)- a pressure group was detained for two years on charges of inciting public unrest in eastern Nigeria.

Equally worrisome is the decline of media freedom in Nigeria since 2015- an indication of deliberate state-sponsored attempt to further and arbitrarily silence the press. In 2015, a new legislation, an addition to existing draconian laws that date back to military rule, was passed into law. The Cybercrime Act, according to Reporters Without Border (2019) can be widely used to arrest and prosecute vocal journalists and bloggers in an arbitrary manner. The Act is another step in the autocratic direction; further leading to a decline in press freedom in Nigeria. The report further indicated that the current administration of Mohammad Buhari must do more to protect journalist. In 2019, officers of the Nigerian Army raided the premises of DailyTrust newspaper in Maiduguri, Lagos and Abuja over allegations that the newspaper published information that the administration deemed sensitive about its military offensive on Boko Haram and Islamic State's West Africa. Most participants agreed that the incident was another example of using military and police officers to routinely gag the press. A Punch reporter added that government officials often restrict journalists particularly when the latter investigate or report corruption scandals, human rights abuse or executive privilege. The raid on Trust is seen as part of a wider pattern of clamping down media freedom in Nigeria. Other similar incidents include the arrest of Jones Abiri on charges of terrorism and Samuel Ogundipe of Premium Times for not disclosing the source of his news story. According to Campbell (2019), "DAAR Communications, owner of African Independent Television and RayPower FM radio had it license suspended indefinitely, allegedly for... the presence of hate speech and suspect information from social media." These media raids, arbitrary arrests and indefinite detentions violate rule of law and constitutional procedures. 
The study also found little media effect on development initiative and policy formulation. Responding to questions on links between media reporting and state-efficiency, most reporters agreed that the Nigerian state operates in isolation with little or no regard for news reports and/or public opinion. An Abuja editor commented that, "in spite of incessant calls for reform of anti-corruption organisations, especially the Economic and Financial Crimes Commission (EFCC) to make it truly independent and well-resourced, the Nigerian government have shown no interest in bringing about changes that will improve the system. Other participants cited other examples such as, closure of national borders in Lagos and Port Harcourt in 2019 without due consultation with all stakeholders. The current governments simply imposed its will without caution. Another example is the introduction of RUGA settlement- an initiative of the Federal Government to settle Hausa migrant pastoral families, herdsmen and cattle farmers in newly created, organised rural sites particularly in southern states. This created so much backlash that the government had to back down on its implementation- another policy failure due to top-down government decision making. Here again we see a glaring error in judgement of the state to engage with or at least listen to media reports and public sentiments. An Abuja reporter observed that, "Although the media will continue to voice concerns about these serious issues, the current government of President Mohammed Buhari seems unperturbed by media reporting". According to a Trust editor "what we have in Nigeria is a dysfunctional country with misguided policies and priorities but every four years, particularly at election season, we manage to get it right politically. Thereafter, chaos is reproduced for another four years."

\section{Conclusion}

This paper, located within the context of democratization in Africa, situated Nigeria's news media within the current political dispensation to investigate the effects, if any, of media power on Nigeria's consolidating democracy. Specifically, it examined if mediapower shaped elections and regime outcomes. Using semi-structured interviews and News Game research tool, the study found that news commercialisation, unfiltered fake news on social media and Nigeria's regionally-divided press have increased public distrust in the news media. In spite of what Adesoji described as media proliferation since 1999, press influence is yet to transform Nigeria's political landscape into a transparent and open system conducive for public engagement, collective decision making and national consensus. Particularly in the areas of elections and regime outcomes, Nigerian politics remains the exclusive preserve of a minority few who decide and use state resources and privileges to further personal gains. Beyond periodic elections, most of which are neither free nor fair, politics lacks democratic and decentralized decision making. Evidence also indicates that mass illiteracy and public resignation are exploited by the ruling elite to resist calls by the media for reform. More recently, media clampdown has subtly increased. The current Buhari administration since 2015 has 
shown less sensitivity to news content and media reporting to the point that news neither holds government accountable nor shape elections and regime outcomes.

\section{Recommendation}

Democracy in advanced economies functions best when multiple factors are presentwritten constitution, an independent judiciary, separation of powers, rule of law, a free press and an informed and engaged citizenry. The press particularly plays a central role in reporting and exposing injustice, corruption and elite privilege- essential ingredients that makes politics bear fruits. In the Nigerian context, media agenda must remain focused on political reforms through investigative reporting and expose journalism. Neoliberalism and its emphasis on commercial success within the media is an unstoppable force, not only in the West but across vast territories influenced by American-style news media structure; however, the Fourth Estate in Nigeria must rediscover its founding mission- public service; must exert more pressure on the political class to respect due process, human rights and rule of law; and must live to uphold democracy.

\section{References}

Ade Ajayi, J.F.A. (1965) Christian Missions in Nigeria, 1841-1891: The Making of a new elite. North-western University Press.

Adesoji, A. (2010) Old Wine in New Bottle: The Nigerian Press in the Era of Constitutional Democracy, 1999-2009. The Journal of International Social Research Volume 3 / 10. Retrieved from: http://www.sosyalarastirmalar.com/cilt3/sayi10pdf/Adesoji.pdf 15/07/2016).

Afigbo, E.A. (2006) The Abolition of the Slave Trade in South-eastern Nigeria, 1885-1950. University of Rochester Press.

BBC News report on: The Nigerian Media. Retrieved from: https://monitoring.bbc.co.uk/product/c200m578

Campbell, J. (2019) Attacks on the Media Continue Unabated in Nigeria. Retrieved from: https://www.cfr.org/blog/attacks-media-continue-unabated-nigeria

BBC News (2019) Omoleye Sowore: Nigerian journalist detained hours after release. Retrieved from: https://www.bbc.com/news/world-africa-50689265

Coleman, J. (1971) Nigeria: Background to Nationalism. Berkeley: University of California press. pp. 225-230.

Graber, D. (2003) The Media and Democracy: Beyond Myths and Stereotypes. Annual Review of Political Science. Vol. 6: 139-160.

Hoffmann, L.K. (2014) Who Speaks for the North? Politics and Influence in Northern Nigeria. London: Chatham House.

Hopkins, A.G. (1975) Economic History of West Africa. London: Longman.

Ikime, O. (1980) Groundwork of Nigerian History. Ibadan: Heinemann Educational Books. 
Keane, J. (1991) The Media Democracy. Cambridge: Polity Press.

Kitzinger, J. (1994) Focus group methodology: the importance of interaction between research participants', Sociology of Health and Illness, 169(1): 103-21.

Kukah, M. (1999) Democracy and Civil Society in Nigeria. Ibadan: Spectrum Books.

Lippmann, W. (1922) Public Opinion. New York: The Free Press.

MacBride Report (1980) Many Voices, One World. Paris: UNESCO. Retrieved from: https://unesdoc.unesco.org/ark:/48223/pf0000040066

McChesney, R. (2000) Rich Media, Poor Democracy: Communication Politics in Dubious Times. New York: The New Press.

McCombs, M. \& Shaws, P. (1972) The Agenda-Setting function of the Mass Media. Public Opinion Quarterly, 36, 176-184.

McCombs, M. \& Shaws, P. (eds. 1977) The Emergence of American Political Issues: The Agenda-Setting Function of the Press. St. Paul MN: West. pp. 89-105.

McCombs, M.E. (1991) Agenda-Setting: Reading on Media, Public Opinion and Policy Making. Hillsdale, New Jersey: Lawrence Erlbaum Associates.

Newton, N. (2014) The use of semi-structured interviews in qualitative research: strengths and weaknesses. Retrieved from: https://www.academia.edu/1561689/The use of semistructured interviews in qualitative research strengths and weaknesses4

Omu, F. (1978) Press and Politics in Nigeria 1856-1937. Ibadan: Longman.

Oso, L. (2011) Press and Politics in Nigeria- on whose side? 47th Inaugural Lecture of the Lagos State University.

Ostgaard, E. (1965) Factors Influencing the Flow of News. Journal of Peace Research, 2(1) 39-63

Otite, O. (1990) Ethnic Pluralism and Ethnicity in Nigeria. Ibadan: Shaneson Ltd.

Randall, V. (1993) The Media and Democratisation in the Third World, Third World Quarterly, 14(3), 625-646

Reporters Without Borders (2019) Climate of Permanent Violence. Retrieved from: https://rsf.org/en/nigeria

Robertson, A. (2015) Media and Politics in a Globalizing World. Cambridge: Polity

Senghore, A. (2012) Press freedom and democratic governance in The Gambia: A rightsbased approach. African Human Rights Law Journal. Retrieved from:

https://pdfslide.net/documents/press-freedom-and-democratic-governance-in-thegambia-a-rights-.html

Siollun, M. (2013) Soldiers of Fortune: Nigerian Politics from Buhari to Babangida (1983 to 1993). Lagos: Cassava Republic Press.

Sklar, R. (1963) Nigerian Political Parties: Power in an Emergent African Nation. Princeton University Press.

Wasserman, H. \& Madrid-Morales, D. (2019) An Exploratory Study of "Fake News" and Media Trust in Kenya, Nigeria and South Africa, African Journalism Studies, 40(1), 107-123. 
Windhoek Declaration (1991) https://misa.org/issues-we-address/the-1991-windhoekdeclaration/

Wood, D. (1983) Mass Media and the Individual. California: West Publishing Company. 